\title{
Reference Books of 1951-1952
}

Miss Winchell is reference librarian, Columbia University.

\section{Introduction}

A $\mathrm{S}$ IN PREvious articles in this series ${ }^{1}$ 1 this survey is based on notes written by members of the Reference Staff of the Columbia University Libraries. Because of the expressed preference of some reference librarians for an annotated bibliography instead of a survey article, the form has been changed in this issue. The main purpose, however, remains the same, to list a selection of scholarly and foreign works which seem to have special importance for university libraries. Therefore, it is not a comprehensive and well-balanced list, and with the exception of two titles, the sciences and technologies have again been omitted. Code numbers (such as $\mathrm{N}_{25}$ ) have been used to refer to titles in the Guide to Reference Books, ${ }^{2}$ seventh edition.

\section{Bibliography}

Tremaine, Marie. A Bibliography of Canadian Imprints, I75I-I80o. Toronto, University of Toronto Press, 1952. 705p.

A full record of what is known of the first fifty years of the provincial press. Books, magazines, pamphlets, newspapers, broadsides, and handbills are listed, including those actually issued and those known to have been projected. Full bibliographical information is given for each item and copies are located in Canadian, American and foreign libraries. Good descriptive

1 College and Research Libraries, 13:30-36, 234-4I, Jan., July, 1052. Chicago, ALA, I95I. notes make this a guide to the society and thought of the period. There is a section on printing offices and a good general index to the volume.

Wing, Donald Godard. Short-Title Catalogue of Books Printed in England, Scotland, Ireland, Wales, and British America and of English Books Printed in Other Countries, I64I-I70o. New York, Printed for the Index Society by Columbia University Press, I95I. v. 3, 52 I p.

For v. I-2 see Guide, A302. The last volume of this important set.

\section{Index Bibliographicus: Directory of Current} Periodical Abstracts and Bibliographies; répertoire des revues courantes de bibliographies analytiques et signalétiques. Compiled by Theodore Besterman. The Hague, UNESCO, I952- . v. I. Science and Technology. 52p. Ist ed., Geneva, I925; 2nd ed., Berlin, I931. (A I6)

This third edition continues the earlier work but presents in completely revised form bibliographies and abstract journals arranged by the Universal Decimal Classification. The first volume covers Science and Technology, the second is to cover the social sciences, education, and humanistic studies. Indication is given of language of abstracts, comprehensive or select coverage, annual number of entries, address of publisher, etc. There are subject indexes in English and French and a title index.

Periodicals and Newspapers

U. S. Library of Congress. Serial Titles Newly Received, I95I- . Washington, 
Library of Congress, Card Division, I952- . Annual vol. \$16.50; Monthly issues and annual vol. \$25.00.

Published monthly, cumulating annually, this is the annual cumulation of the monthly issues published during 195 I. Form of entry in this volume differs from standard ALA cataloging rules, but in the 1952 issues entry follows ALA rules. Includes titles of serials not previously recorded in the Library of Congress serial record, but excludes newspapers, comic books, telephone books, and trade catalogs.

U. S. Library of Congress. Reference Department. Serial Publications of the Soviet Union, 1939-195I. A Preliminary Checklist. Washington, 195 I. 316p. \$I.5O.

Special supplement to Monthly List of Russian Accessions.

Titles are transliterated and there is a ;ubject index in English.

U. S. Library of Congress. Slavic Division. Preliminary Checklist of Russian, Ukranian, and Belorussian Newspapers Published since January I, I9I7, within the Present Boundaries of the USSR and Preserved in United States Libraries. (A working paper) compiled by Paul L. Horecky. Washington, 1952. 97p.

Based mainly on the collections in the Library of Congress, with some added locations for newspapers in other libraries in the United States, although coverage is not complete. It is hoped that more extensive holdings can be included in a final edition.

Arranged alphabetically by place of publication giving for each title, issuing body, frequency, and date of establishment, and changes in location, title, frequency or issuing body.

\section{Libraries}

American School Library Directory ; a Geo- graphical List of School Libraries with Statistical Data. N.Y., R. R. Bowker Co., I952- . Loose-Leaf \$I 5.00.

Pt. I, Southern States. I68p.

To be issued in four parts. The first, covering the twelve southern states, lists 6969 school libraries including public high schools, junior high schools and elementary schools and private and parochial schools. Arranged by state and then alphabetically by city. For each school attempts to give name, mailing address, with data on grades, enrollment, number of volumes in the library and the annual library book budget, including both state and local funds. General information about the school library system of each state is given at the beginning of each state list. Names and addresses are given for state, county, and city library supervisors but not for school librarians.

\section{Government Documents}

Moor, Carol Carter and Chamberlin, Waldo. How to Use United Nations Documents. New York, New York University Press, 1952. 26p. \$I.50. (New York University Libraries. Occasional Paper, No. I.)

A manual prepared primarily for use with a complete collection of United Nations documents, including all unrestricted mimeographed, processed, and printed material.

In four parts: Pt. I, a discussion of the methods and problems of research; Pt. II, a commentary on and lists of the five basic tools and guides; Pt. III, a list of tools and guides by the organs of the United Nations; Pt. IV, a selected subject guide based on the seventeen subject categories used in the United Nations Sales Number series.

Should be useful in any library collecting United Nations documents.

Zinn, Charles J. How Our Laws Are Made. [St. Paul, Minn.] West Pub. 
Co. and Edward Thompson Co., 1952. 4op.

Reprinted from U.S. Code Congressional and Administrative Service.

An excellent brief description of the federal legislative process, including a discussion of bills and resolutions, their introduction to the House and reference to Committee, hearings, reported bills, calendars, consideration by the House, Senate action, presidential action, publication as slip laws, statutes at large, U.S. Code, etc.

Should be useful to librarians and to students who must trace legislation through the Congress.

\section{Religion}

Garnot, Jean Sainte Fare. Religions égyptiennes antiques; bibliographie analytique (1939-1943). Paris, Presses Universitaires de France, 1952. $277 \mathrm{p}$.

A republication of a series of articles on Egyptian religions which appeared in the Revue de l'histoire des religions from I9441950, now arranged by subject in one volume, thus presenting a survey of Egyptian religions accompanied by critical references. The lack of an index will detract from its value as a reference work.

\section{Dictionaries}

Ostermann, Georg F. Manual of Foreign Languages for the Use of Librarians, Bibliographers, Research Workers, Editors, Translators, and Printers. 4th ed., rev. and enl. New York, Central Book Co., 1952. $4 \mathrm{I} 4 \mathrm{p}$.

3rd ed. I936, pub. by The Government Printing Office.

"All portions of the third edition not requiring change have been reproduced in this new edition by the photographic process. Corrections and minor additions have been 'stripped in,' and all new material, set in type for the first time, is presented in a format approximating as closely as possible that used in the third and prior edition." Pref.

Some languages have undergone extensive revision, and Estonian has been added.

\section{Pattermann, Wilhelm. Deutsch-englisches}

Wörter- und Phrasenbuch, mit Berücksichtigung des amerikanischen Englisch. Wien, Alexa-Verlag, 1949-1952. 2v.

Lists up-to-date English and American equivalents of German words and expressions, under key-word, placing emphasis on the shade of meaning implied by use in a particular context. Does not list all possible translations of individual words nor give etymologies.

Spalding, Keith. An Historical Dictionary of German Figurative Usage. Oxford, Blackwell, ı 952- . Fasc. I, A-Anfühlen.

Records figurative expressions, proverbs, quotations, and other established phrases appearing in German literature since approximately I750; annotations illustrating use and change of meaning are often drawn from sources which precede this date. English translations for each entry are equivalent, not literal. A complete list of sources is planned for the conclusion of the work.

\section{Science}

Sarton, George. Horus: $A$ Guide to the History of Science; A First Guide for the Study of the History of Science with Introductory Essays on Science and Tradition. Waltham, Mass., Chronica Botanica Co., 1952. 316p. \$7.50.

The first section is composed of three lectures on the history of science and the second section is a bibliographical summary prepared as a guide to students of the history of science. Part 2 is divided into four main sections each subdivided: History, Science, 
History of Science, Organization of the Study and Teaching of the History of Science.

\section{World List of Scientific Periodicals Pub-} lished in the Years 19oo-1950. 3rd ed. New York, Academic Press, I952. I058p. \$37.00.

Ist ed., I925-27; 2nd ed., I934 (N25).

Like the earlier editions, this third edition is a finding list of titles in the sciences, indicating holdings in British libraries. New features are the inclusion of data on titles not held by any library in the United Kingdom, and an English index to subjectwords of International Congresses. Society and subject indexes have again been omitted for financial reasons.

\section{Art and Architecture}

American Art Directory, ed. by Dorothy B. Gilbert. New York, Bowker, I952. (American Federation of Arts). 373p. $\$ 17.50$.

Formerly appeared as the American Art Annual (Q26), which included Who's Who in American Art (Q59) (now published separately). To appear triennially.

Lists museums, art organizations, universities and colleges having art departments, art schools and classes, in the United States, Canada and Latin America. Also lists art magazines, newspapers carrying art notes, museum publications, traveling exhibitions available, etc. The index includes subject references to museum collections.

Saylor, Henry Hodgman. Dictionary of Architecture. New York, Wiley, 1952. 22 I p. il. $\$ 4.50$.

Gives concise definitions of terms used in the practice and historical reading of architecture. Pronunciation is indicated by phonetic spelling.
Music

Clough, Francis F. and Cuming, G. J. The World's Encyclopaedia of Recorded Music. London, Sidgwick and Jackson; New York, London Gramophone Corp., 1952. 890p. \$I 7.5O.

Based on Darrell's I936 Gramophone Shop Encyclopedia of Recorded Music (Q 315). A comprehensive listing of all electrically-recorded music of worth-while interest to June I95I, and of pre-electrical recordings of unique value. Information is detailed and the arrangement convenient. Will be indispensable in any collection interested in recorded music.

Listings of recordings from April I950May/June I95 I are given in the First Supplement, p. 725-86o.

Darrell, Robert Donaldson. Schirmer's Guide to Books on Music and Musicians; a Practical Bibliography. New York, Schirmer, I95 I. 402p. \$6.00.

An annotated guide to currently available books on music and musicians, omitting collections of music itself. Arranged alphabetically in dictionary form with many cross-references. The main alphabet lists books in English only, but there are appendices giving selected lists of books in French, German, Spanish, Italian and Latin. Does not usually include out-of-print books except in annotations. Full bibliographical information is given under subject with cross-reference from author.

\section{Theater}

Granville, Wilfred. The Theater Dictionary: British and American Terms in the Drama, Opera, and Ballet. New York, Philosophical Library, [I952] 227p. $\$ 5.00$.

This dictionary of technical, colloquial, and slang speech of the twentieth century 
stage lists in one alphabet, general, British, and American terms, but is done mainly from the British point of view. American synonyms are frequently given under British terms with no main entries or cross-references: thus, "bouncer" is not in its alphabetical place but under "chucker out," and "Annie Oakley" as a free ticket is under "brief." Although this arrangement will detract from the book's general usefulness in American libraries, information not easily available elsewhere will be found here about some unusual words and phrases.

\section{Literature}

Adams, Franklin Pierce. FPA Book of Quotations: $A$ New Collection of $F a$ mous Sayings, Reflecting the $W$ isdom and Wit of Times Past and Present and Including the Virtuous, Humorous, and Philosophic Commentary on Life by Men and Women of Every Age together with Riches from the Profound $W$ ells of the Bible, Proverbs, and Anonymity. New York, Funk and Wagnalls, I952. 9I 4p. $\$ 5.95$.

A new general collection including more than I 5,000 quotations grouped under topics, and under topic arranged alphabetically by author. There is an index of topics with cross-references and an index of authors, but no word-index. The selection is broad with quotations from well-known sources as well as from less-known writers, with a fair number from modern writers and speakers. In some cases references to sources are given in full and in others, reference is to author and title or author only. Dates of birth and death are given for authors.

Hamilton, Robert M. Canadian Quotations and Phrases, Literary and Historical, with an Introduction by Bruce Hutchison. Toronto, McClelland and Stewart, 1952. 272p.
A collection of quotations and phrases from Canadian authors and from nonCanadians on subjects distinctly Canadian. Arranged by topic with author index. Reference is usually, but not always, to exact source.

Halliday, Frank Ernest. A Shakespeare Companion, I550-I950. New York, Funk and Wagnalls, 1952. 742p. il. $\$ 8.50$.

Bibliography, p. 720-742.

Varied aspects of Shakespeareana are treated in this alphabetically-arranged handbook, including primarily Shakespeare's life, his friends and contemporaries; his works; the Elizabethan-Jacobean theater, dramatists and theatrical companies; and the history of Shakespeare's work on the stage, his printers and publishers, players, editors, scholars and critics, etc. A selected bibliography and a group of illustrations intended to form a pictorial summary follow.

Dictionnaire des lettres françaises, publié sous la direction de Monseigneur Georges Grente. Paris, Arthème Fayard, I95 ILe seizième siècle. 7 I $8 \mathrm{p}$.

This is the first complete volume to appear of this scholarly dictionary of French literature, although two fascicles, one for the Middle Ages and one for the seventeenth century, were published before the war. No longer to be issued in fascicles, future volumes will cover from the Middle Ages to the twentieth century, and the set will be complete in six volumes.

Alphabetically arranged, the dictionary includes articles varying from a few lines to several pages, on persons, academies, universities and literary subjects. Articles are signed and include extensive bibliographies of the works of authors, and of materials to consult about persons or subjects.

Topete, José Manuel. A Working Bibliog- 
raphy of Latin American Literature, published by Walter B. Fraser, Chairman of the Inter-American Center of Florida, in cooperation with the Inter-American Bibliographical and Library Association and the School of Inter-American Studies, University of Florida. St. Augustin, Florida, 1952. I62p. (Inter-American Bibliographical and Library Association. Ser. I, v. I 2).

A useful guide arranged by country listing: histories of literature, anthologies, bibliographies, criticisms, translations, etc. Author index.

\section{Biography}

Who Was Who, I94I-1950; a Companion to Who's Who Containing the Biographies of Those Who Died During the Decade I94I-I950. London, A. and C. Black, I952. I277p.

The fourth volume in this series. For earlier issues see Guide Sizo.

\section{Who's Who in the South and Southwest;} a Biographical Dictionary of Noteworthy Men and Women of the Southern and Southwestern States. Chicago, A. N. Marquis, I952. 85 I p.

One of the series of Marquis's sectional Who's Whos. This covers Alabama, Arkansas, the District of Columbia, Florida, Georgia, Kentucky, Louisiana, Mississippi, North Carolina, Oklahoma, South Carolina, Tennessee, Texas and Virginia.

Who's Who in Switzerland, Including the Principality of Lichtenstein, I950/5I. Edited by H. and E. Girsberger. Zurich, Central European Times, 1952. 752p. \$12.50. (Distributed by Stechert-Hafner).

A new Swiss biographical dictionary published in English, which includes about 3300 sketches of Swiss nationals at home and abroad, and foreigners residing in Switzerland. Added features are an extensive classified list of organizations, associations, and institutions with separate word indexes in three languages, English, French, and German; a list of European abbreviations; and an index of Swiss terms.

\section{Osterreicher der Gegenwart; Lexikon} schöpferischer und schaffender Zeitgenossen. Wien, Osterreichische Staatsdruckerei, I95I. 4I9p.

Bio-bibliographical data is given on about 2650 outstanding living Austrians, the term Austrian being understood to include persons born in Austria and those born in the old monarchy and now living and working in Austria; foreigners are included only if they have become Austrian citizens or are active within the country. Many scholars in academic fields, who can be found in Kürschners Deutscher Gelehrten-Kalen$d e r$, have been omitted but may be included in later editions.

There is a listing of persons who died while the work was in process, an index by profession or field, and a list by key-number of periodicals referred to in the bibliographies.

Coppe, Paul and Pirsoul, Lèon. Dictionnaire bio-bibliographique des littérateurs d'expression wallonne, I622 à 1950 . Gembloux, Duculot, [I95I] 4I5p.

This bio-bibliographical dictionary includes I 325 sketches and lists some 25,000 titles of works in the Walloon dialect. The sketch of each author indicates the place and date of birth and death, pseudonym, if any, profession, a concise, critical note on the value of his contribution and the titles of his works. Bibliographical information is brief, usually consisting of title and date (in some cases the dates are omitted). 
History

Billington, Ray Allen. Guides to American History Manuscript Collections in Libraries of the United States. New York, Peter Smith, I952. p.467-496. (Repr. from Mississippi Valley Historical Review, v.38, No.3, Dec. 1952).

A listing of guides to manuscript collections in federal depositories, university and public libraries, historical societies, and private libraries which are open to the public. In two parts: ( I) Federal Depositories, including the National Archives and the Library of Congress; (2) States arranged (a) union guides which list collections in a wide number of depositories and (b) guides to single depositories.

Published to aid historians until the union catalog of manuscript collections projected by the American Historical Association is completed.

Koray, Enver. Türkiye tarih yayinlari bibliyografyasi, I729-I950. Ankara, Millî Eğitim Basimevi, I 952. 548p.

A bibliography of Turkish historical writings listing more than 4000 items and divided into two main sections, I 729-1928 and I928-1950, according to the alphabet used. Each of the two parts lists, first, general works, collections, encyclopaedias, etc., followed by books on the history of individual countries, and then works in related fields such as archaeology, biography, and ethnology. Information given for each item is very brief, and there are no annotations. The index includes titles as well as authors.

Saba, Mohsen. Bibliographie française de l'Iran. Bibliographie méthodique et raisonnée des ouvrages français parus depuis ${ }_{5} 60$ jusqu'a nos jours. 2. ed. rev. et augm. Téhran, I95I. 297p.

I. ed. 1936. Covers books and periodical articles in all fields.
Svenska Arkeologiska Samfundet. Swedish Archaeological Bibliography, I939-I948. ed. by Sverker Janson and Olof Vessberg. Uppsala, Almqvist \& Wiksells boktryckeri, 1951. 36op. $25 \mathrm{Sw}$. Cr.

A survey in English of Swedish archaeological literature for a ten-year period. It is the intention of the Society to continue the bibliography, possibly for five-year periods.

Weber, Shirley Howard, comp. Voyages and Travels in the Near East Made During the XIX Century; Being a Part of a Larger Catalogue of Works on Geography, Cartography, Voyages, and Travels, in the Gennadius Library in Athens. Princeton, The American School of Classical Studies at Athens. I952. 252p.

The Gennadius Library in Athens is a rich and unique collection of over 55,000 books, pictures and maps relating to Greece, the Balkans, and the Near East from medieval to modern times. This first part of the catalog of the Library to be published contains I 206 annotated titles, representing only a portion of the material on geography and travel in the Library. The titles are entered by date of publication; a general index and a name index of travelers and authors are given at the end of the volume.

Wjacstawk, Jakub. Serbska bibliografija, 2. rozmnoženy a wuporjedźany naklad; Sorbische (Wendische) Bibliographie, 2. erw. und verb. Aufl. Jacob Jatzwauk. Berlin, Akademie-Verlag, I952. 500p. (Berichte über die Verhandlungen der Sächsischen Akademie der Wissenschaften zu Leipzig. Phil.-Hist. Kl. Bd. 98, Hft. 3)

Ist ed. 1929.

A much enlarged edition of a classified bibliography listing all books and articles in periodicals and newspapers published in the Lusatian (Wendish) language, and all books and articles concerning Lusatia. 